\title{
THE USE OF Pomacea canaliculata SNAILS IN FEED TO IMPROVE QUALITY OF ALABIO DUCK (Anas plathyrinchos Borneo) MEAT
}

\author{
A. Subhan ${ }^{\mathbf{1}, \mathbf{2}}$, T. Yuwanta ${ }^{\mathbf{1}}$ Zuprizal $^{\mathbf{1}}$ and Supadmo ${ }^{\mathbf{1}}$ \\ ${ }^{1}$ Faculty of Animal Science, Gadjah Mada University, \\ Jl. Fauna 3, Kampus UGM, Bulaksumur, Yogyakarta 55281 - Indonesia \\ ${ }^{2}$ Permanent Address: Assessment Institute of Agricultural Technology, \\ Jl. P. Batu Barat No. 4 Banjarbaru, Kalimantan Selatan - Indonesia \\ Corresponding E-mail : ahmadsubhan1970@gmail.com
}

Received August 17, 2015; Accepted November 05, 2015

\begin{abstract}
ABSTRAK
Penelitian ini bertujuan untuk mengetahui penggunaan keong mas dalam pakan itik Alabio yang dipelihara secara intensif untuk meningkatkan kualitas daging secara fisik dan kimia. Sembilan perlakuan yaitu R0 (pakan kontrol), R1 (pakan basal $+2.5 \%$ keong mas lebak), R2 (pakan basal $+5 \%$ keong mas lebak), R3 (pakan basal $+7.5 \%$ keong mas lebak), R4 (pakan basal $+10 \%$ keong mas lebak), R5 (pakan basal $+2.5 \%$ keong mas pasang surut), R6 (pakan basal $+5 \%$ keong mas pasang surut), R7 (pakan basal $+7.5 \%$ keong mas pasang surut), R8 (pakan basal $+10 \%$ keong mas pasang surut). Variabel yang diamati meliputi kualitas fisik dan kimia daging. Dengan metode Rancangan Acak Lengkap (RAL) pola searah dilakukan analisis varians, dan dilanjutkan dengan Uji Jarak Berganda Duncan. Hasil penelitian menunjukan bahwa penggunaan keong mas dalam pakan memberikan pengaruh nyata $(\mathrm{P}<0.05)$ terhadap sifat fisik (daya ikat air, susut masak dan keempukan/tenderness), dan kimia daging itik Alabio (air, protein, kolagen, lemak, dan kolesterol). Namun tidak berpengaruh terhadap $\mathrm{pH}$ daging. Kesimpulan dari penelitian ini bahwa penggunaan keong mas sebanyak 5\% dalam campuran pakan basal itik Alabio menghasilkan susut masak dan kolesterol daging rendah.

Kata kunci: kualitas daging, itik Alabio, keong mas
\end{abstract}

\begin{abstract}
This research was aimed to improve the physical and chemical quality of Alabio ducks which was fed with Pomacea canaliculata snails. Those ducks were raised intensively. There were nine treatments included R0 (control feed), R1 (control feed $+2.5 \%$ Pomacea canaliculata snails from swampy area), R2 (control feed $+5 \%$ Pomacea canaliculata snails from swampy area), R3 (control feed $+7.5 \%$ Pomacea canaliculata snails from swampy area) R4 (control feed $+10 \%$ Pomacea canaliculata snails from swampy area) R5 (control feed $+2.5 \%$ Pomacea canaliculata snails from tidal swampy area), R6 (control feed $+5 \%$ Pomacea canaliculata snails from tidal swampy area, R7 (control feed $+7.5 \%$ Pomacea canaliculata snails from tidal swampy area, and R8 (control feed $+10 \%$ Pomacea canaliculata snails from tidal swampy area. The variables observed included meat chemical and physical quality. A Completely Randomized Design was used in this study. Analysis of variance and Duncan's multiple range test were used to analyze data. The research results revealed that using Pomacea canaliculata snails in duck feed had a significant effect $(\mathrm{P}<0.05)$ towards the physical characteristics (water holding capacity, cooking loss, and tenderness), and chemical characteristics of
\end{abstract}


Alabio duck meat (water, protein, collagen, fat, and cholesterol content). However, there was no significant effect towards meat $\mathrm{pH}$. It can be concluded that using 5\% Pomacea canaliculata snails in a mixture of Alabio duck feed decreased cooking loss and meat cholesterol content.

Keywords: meat quality, Alabio duck, Pomacea canaliculata snails

\section{INTRODUCTION}

Numerous efforts have been already done to improve the quality of duck meat, whether in treatments before being slaughtered or in treatments afterwards. The addition of Pomacea canaliculata snails in feed is a relatively applicable as an alternative supplement in duck feed, because the majority of duck breeders in South Kalimantan have already used it as an ingredient in Alabio duck feed formulation.

In South Kalimantan these Pomacea canaliculata snails are found in swampy areas both tidal marsh and lowland swamp. Those two areas have different characteristics. The tidal areas are located near the beach, so that when the tide happened sea water brought the marine biota as snails feed. While lowland swamp water comes from rain water and surface water so that the source of food of snails also originated from that location (Noor, 2004)

Pomacea canaliculata snails contain high unsaturated fatty acid such as: oleic acid $20.37 \%$, linoleic acid $20.26 \%$, and linolenic acid $12.83 \%$ (Subhan et al., 2010). Linoleic acid is an essential fatty acid, a fatty acid that cannot be produced in the body, so it must be consumed from food (Astawan, 2009). Kinsella et al. (1990) reported that the clinical effect of omega-3 fatty acid in reducing cholesterol levels is thought to be due to the effect of the lipoprotein transport production mechanism in the liver that is secreted into the blood. This cholesterol is broken down in the liver to become bile acid and not regenerated again to ultimately be excreted. The longer the carbon chain and the greater the number of double bonds are, the greater the tendency to reduce blood cholesterol levels.

Omega-9 (oleic acid) is one of mono unsaturated fatty acids (MUFA) which has a more stable characteristic and better role compared to poly unsaturated fatty acid (PUFA). PUFA can reduce LDL cholesterol (K-LDL) as well as HDL cholesterol (K-HDL), whereas MUFA can reduce K-LDL but increase K-HDL (Krauss, 2001). Omega-9 (oleic acid) can reduce K-LDL and increase K-HDL greater than Omega-3 (linolenic acid) and Omega-6 (linoleic acid) (Woods et al.,1993). The substitution of saturated fatty acids with unsaturated fatty acids can reduce cholesterol levels, both in the total cholesterol amount and KLDL. Meanwhile, MUFA itself, besides being able to reduce total cholesterol and K-LDL, it can also increase K-HDL more than PUFA. Thus, it will inhibit atherosclerosis (Muller et al., 2003).

The objective of this study was to evaluate the effect of feed containing snails as source of unsaturated fatty acids on the chemical and physical quality of the Alabio ducks meat.

\section{MATERIALS AND METHODS}

\section{Experimental Animals}

The materials used in this research were 180 Alabio female ducks that were 22 weeks old. Those ducks were kept in 36 postal box cages made from wood, bamboo, and mesh wire with a size of $1 \times 1.5 \times 1 \mathrm{~m}$ along with feeding and drinking containers.

\section{Experimental Feed}

The feed materials used in the rations consisted of yellow corn, rice bran, soybean cakes, meat bone meal (MBM), DL- methionine, L- lysine, $\mathrm{NaCl}, \mathrm{CaCO}_{3}, \mathrm{DCP}$, and top mix medion which was formulated based on National Research Council (NRC, 1994) standards, as well as feed treatments that were arranged to replace MBM with Pomacea canaliculata snaisl meal that comes from swampy and tidal swampy area with percentages of $2.5 \%, 5 \%, 7.5 \%$, and $10 \%$ respectively. The materials and composition of experimental feed are listed in Table 1.

\section{Research Procedures}

This research was conducted for 12 weeks, including 2-week of adaptation period for feeding treatment. There were 180 females Alabio ducks distributed randomly according to Completely Randomized Design into 9 treatments and 4 replications with each replications consist of 5 female ducks. The treatments used were consisted of:

$\mathrm{R}_{0} \quad$ : control feed 
Table 1. Ingredients and Composition of Feed Treatments

\begin{tabular}{|c|c|c|c|c|c|c|c|c|c|}
\hline \multirow{2}{*}{ Feed ingredients $(\%)$} & \multicolumn{9}{|c|}{ Treatments } \\
\hline & $\mathrm{R}_{0}$ & $\mathrm{R}_{1}$ & $\mathrm{R}_{2}$ & $\mathrm{R}_{3}$ & $\mathrm{R}_{4}$ & $\mathrm{R}_{5}$ & $\mathrm{R}_{6}$ & $\mathrm{R}_{7}$ & $\mathrm{R}_{8}$ \\
\hline & \multicolumn{9}{|c|}{ 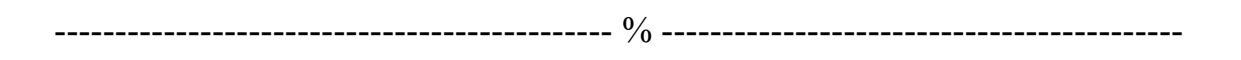 } \\
\hline Yellow corn & 52.00 & 52.00 & 52.00 & 52.00 & 52.00 & 52.00 & 52.00 & 52.00 & 52.00 \\
\hline Rice bran & 17.20 & 17.20 & 17.20 & 17.20 & 17.20 & 17.20 & 17.20 & 17.20 & 17.20 \\
\hline Soybean meal & 17.50 & 17.50 & 17.50 & 17.50 & 17.50 & 17.50 & 17.50 & 17.50 & 17.50 \\
\hline MBM & 10.00 & 7.50 & 5.00 & 2.50 & 0.00 & 7.50 & 5.00 & 2.50 & 0.00 \\
\hline Swampy snails & 0 & 2.50 & 5.00 & 7.50 & 10.00 & 0 & 0 & 0 & 0 \\
\hline Tidal swampy snails & 0 & 0 & 0 & 0 & 0 & 2.50 & 5.00 & 7.50 & 10.00 \\
\hline DL-Methionin & 0.10 & 0.10 & 0.10 & 0.10 & 0.10 & 0.10 & 0.10 & 0.10 & 0.10 \\
\hline L- lysine-HCl & 0.10 & 0.10 & 0.10 & 0.10 & 0.10 & 0.10 & 0.10 & 0.10 & 0.10 \\
\hline $\mathrm{NaCl}$ & 0.25 & 0.25 & 0.25 & 0.25 & 0.25 & 0.25 & 0.25 & 0.25 & 0.25 \\
\hline $\mathrm{CaCO} 3$ & 2.50 & 2.50 & 2.50 & 2.50 & 2.50 & 2.50 & 2.50 & 2.50 & 2.50 \\
\hline $\mathrm{DCP}$ & 0.10 & 0.10 & 0.10 & 0.10 & 0.10 & 0.10 & 0.10 & 0.10 & 0.10 \\
\hline Premix * & 0.25 & 0.25 & 0.25 & 0.25 & 0.25 & 0.25 & 0.25 & 0.25 & 0.25 \\
\hline Total & 100.00 & 100.00 & 100.00 & 100.00 & 100.00 & 100.00 & 100.00 & 100.00 & 100.00 \\
\hline \multicolumn{10}{|l|}{ Nutrients content $* *$} \\
\hline Energy (Kcal/kg) & 2896.1 & 2886.0 & 2876.0 & 2865.9 & 2855.9 & 2885.3 & 2874.5 & 2863.7 & 2852.9 \\
\hline Protein $(\%)$ & 20.11 & 20.16 & 20.20 & 20.25 & 20.29 & 20.08 & 20.06 & 20.03 & 20.00 \\
\hline Crude fiber (\%) & 4.07 & 4.06 & 4.09 & 4.10 & 4.10 & 4.07 & 4.07 & 4.07 & 4.08 \\
\hline Crude fat $(\%)$ & 5.39 & 5.20 & 5.01 & 4.82 & 4.63 & 5.20 & 5.01 & 4.82 & 4.63 \\
\hline $\mathrm{Ca}(\%)$ & 2.13 & 2.68 & 3.24 & 3.79 & 4.35 & 2.66 & 3.20 & 3.74 & 4.27 \\
\hline P (\%) & 1.04 & 0.94 & 0.84 & 0.73 & 0.63 & 0.94 & 0.84 & 0.73 & 0.63 \\
\hline Methionine (\%) & 0.33 & 0.31 & 0.29 & 0.27 & 0.27 & 0.31 & 0.29 & 0.27 & 0.27 \\
\hline Lysine $(\%)$ & 0.41 & 0.42 & 0.43 & 0.44 & 0.45 & 0.42 & 0.43 & 0.44 & 0.45 \\
\hline Oleic (\%) & 1.54 & 2.06 & 2.59 & 3.12 & 3.64 & 1.96 & 1.38 & 2.79 & 3.21 \\
\hline Linoleate (\%) & 2.18 & 2.46 & 2.74 & 3.02 & 3.30 & 2.46 & 2.75 & 3.04 & 3.32 \\
\hline Linolenate $(\%)$ & 0.06 & 0.29 & 0.51 & 0.74 & 0.96 & 0.33 & 0.60 & 0.87 & 1.13 \\
\hline
\end{tabular}

*Premix: each kg contains: Vitamin A: $12.000 \mathrm{IU}$, Vitamin D: $2.000 \mathrm{IU}$, Vitamin E: $8.000 \mathrm{IU}$, Vitamin K: $2 \mathrm{mg}$, Vitamin B1: $2 \mathrm{mg}$, Vitamin B2: $5 \mathrm{mg}$, Vitamin B6: $500 \mathrm{mg}$, Vitamin B12: $12.000 \mathrm{ug}$, Vitamin C: $25 \mathrm{mg}$, CalciumD-panthothenate: $6 \mathrm{mg}$, Niacin: $40 \mathrm{mg}$, Choline chloride: $10 \mathrm{mg}$, Methionine: $30 \mathrm{mg}$, Lysine: $30 \mathrm{mg}$, Manganese: $120 \mathrm{mg}$, Iron: $20 \mathrm{mg}$, Iodine: $200 \mathrm{mg}$, Zinc: $100 \mathrm{mg}$, Copper : $200 \mathrm{mg}$ Cobalt :4 mg, Zinc Bacitracin: $21 \mathrm{mg}$ ** Standard duck needs for layer ( NRC, 1994)

$\mathrm{R}_{1}:$ control feed $+2.5 \%$ Pomacea $\quad \mathrm{R}_{2}:$ control feed $+5 \%$ Pomacea canaliculata snails from swampy area) canaliculata snails from swampy area 
$\mathrm{R}_{3}$ : control feed $+7.5 \%$ Pomacea canaliculata snails from swampy area

$\mathrm{R}_{4}$ : control feed $+10 \%$ Pomacea canaliculata snails from swampy area

$\mathrm{R}_{5}$ : control feed $+2.5 \%$ Pomacea canaliculata snails from tidal swampy area

$\mathrm{R}_{6}:$ control feed $+5 \%$ Pomacea canaliculata snails from tidal swampy area

$\mathrm{R}_{7}$ : control feed $+7.5 \%$ Pomacea canaliculata snails from tidal swampy area

$\mathrm{R}_{8}:$ control feed $+10 \%$ Pomacea canaliculata snails from tidal swampy area

At the age of 34 weeks (near the $1^{\text {st }}$ molting), 1 duck of each treatment unit was slaughtered by using an appropriate method. The (carotid artery, vena jugular, and esophagus were cut for bleding. Then, it was continued by removing the feathers by first submerging the carcass into boiling water $\left(65-80^{\circ} \mathrm{C}\right)$ for $5-30$ seconds. Sample was taken from thighs by cutting the femur and ischium as well as cutting the joints of the fibula/tibia therewith the leg bones. Breast sample was taken by cutting the edge of the breast bone until the corocoid and scapula bones therewith the thorax. The variables observed included the meat physical quality $(\mathrm{pH}$, water holding capacity, cooking loss, and tenderness) and meat chemical quality (water, protein, fat, collagen, and cholesterol content). A Completely Randomized Design was conducted and then followed-up by a Duncan's multiple range test (DMRT).

\section{RESULTS AND DISCUSSION}

\section{Meat Chemical Composition}

\section{Water Content}

This paper found that using Pomacea canaliculata snails in feed has a significant effect $(\mathrm{P}<0.05)$ on Alabio duck meat water content. The R6 treatment (using 5\% Pomacea canaliculata snails from tidal swampy area) produced the highest water level (Table 2). This was due to a reduction in other meat components like protein and fat. This is in line with findings by Amrullah (2004), who found that whenever the percentage of fat in a carcass increases, the water will decrease. The research found that using Pomacea canaliculata snails in feed decreased meat fat levels.

\section{Protein Content}

The average of duck meat protein content were about $20.75-22.11 \%$. The protein content was significantly higher $(\mathrm{P}<0.05)$ as the proportion of Pomacea canaliculata in feed increased. This is because of high protein content in Pomacea canaliculata snails. Besides that, using Pomacea canaliculata snails had also reduce fat content (Table 2), so that the availability of nutrients had been used for increasing the meat protein/muscle mass. This study found that the meat protein contents in R4 and R8 treatments that using 10\% of Pomacea canaliculata snails produced the highest meat protein content by $21.97 \pm 0.41 \%$ and $22.11 \pm$ $0.24 \%$, respectively.

\section{Fat Content}

The research result revealed that there was reduction in meat fat content due to the treatments $(\mathrm{P}<0.05)$. The lowest meat fat content was in $\mathrm{R} 4$ treatment (10\% Pomacea canaliculata snails from swampy area) at $3.92 \pm 0.15 \%$.

\section{Meat cholesterol Concentration}

The average of cholesterol content of Alabio ducks meat which was given Pomacea canaliculata snail treatments in basal feed are shown in Table 2. There was a significant effect of the treatments $(\mathrm{P}<0.01)$ towards the meat cholesterol content. The lowest meat cholesterol concentration $(57.55 \pm 2.54 \%)$ was found in the R2 treatment (5\% Pomacea canaliculata snails from swampy area). The reduction of meat cholesterol content was due to the role of unsaturated fatty acids in Pomacea canaliculata snails that can stimulate cholesterol excretion through the intestines and stimulate cholesterol oxidation to become bile acid. The duck meat cholesterol concentration in this research were lower than the research results reported by Ismoyowati and Sumarmono (2011), in that the average local duck meat cholesterol levels were $185.25 \mathrm{mg} / 100 \mathrm{~g}$. There were meat cholesterol content differences in each of the treatments because of feed consumption differences that also caused differences in fatty acid consumption. Pomacea canaliculata snails contain unsaturated fatty acids that can increase intestinal homeostasis that facilitate destruction mechanism or cholesterol 
Table 2. Feed Consumption and Chemical Characteristics of Alabio Duck Meat (Water, Protein, Fat, Collagen and Cholesterol Content) which was Fed with Snail the Ration.

\begin{tabular}{ccccccc}
\hline Treatments & $\begin{array}{c}\text { Feed } \\
\text { consumptions } \\
(\mathrm{g} / \mathrm{bird})\end{array}$ & Water (\%) & Protein (\%) & Fat (\%) & $\begin{array}{c}\text { Collagen } \\
(\%)\end{array}$ & $\begin{array}{c}\text { Cholesterol } \\
(\mathrm{mg} / 100 \mathrm{~g})\end{array}$ \\
\hline $\mathrm{R}_{0}$ & $12552.50 \pm 25.85$ & $68.32 \pm 0.15^{\mathrm{a}}$ & $21.19 \pm 0.11^{\mathrm{b}}$ & $6.79 \pm 0.12^{\mathrm{f}}$ & $2.29 \pm 0.05^{\mathrm{cd}}$ & $67.02 \pm 2.81^{\mathrm{de}}$ \\
$\mathrm{R}_{1}$ & $12574.25 \pm 17.14$ & $69.84 \pm 0.10^{\mathrm{d}}$ & $21.04 \pm 0.33^{\mathrm{a}}$ & $5.98 \pm 0.18^{\mathrm{d}}$ & $2.15 \pm 0.08^{\mathrm{c}}$ & $61.79 \pm 3.03^{\mathrm{bc}}$ \\
$\mathrm{R}_{2}$ & $12600.00 \pm 10.72$ & $68.77 \pm 0.08^{\mathrm{b}}$ & $20.75 \pm 0.19^{\mathrm{a}}$ & $6.94 \pm 0.17^{\mathrm{f}}$ & $2.16 \pm 0.09^{\mathrm{c}}$ & $57.55 \pm 2.54^{\mathrm{a}}$ \\
$\mathrm{R}_{3}$ & $12573.75 \pm 16.94$ & $69.54 \pm 0.31^{\mathrm{c}}$ & $20.89 \pm 0.16^{\mathrm{a}}$ & $6.39 \pm 0.17^{\mathrm{e}}$ & $2.18 \pm 0.14^{\mathrm{c}}$ & $58.30 \pm 2.49^{\mathrm{ab}}$ \\
$\mathrm{R}_{4}$ & $12574.75 \pm 16.56$ & $70.91 \pm 0.24^{\mathrm{d}}$ & $21.97 \pm 0.41^{\mathrm{d}}$ & $3.92 \pm 0.15^{\mathrm{a}}$ & $1.83 \pm 0.13^{\mathrm{ab}}$ & $69.33 \pm 2.45^{\mathrm{e}}$ \\
$\mathrm{R}_{5}$ & $12574.15 \pm 16.91$ & $69.48 \pm 0.16^{\mathrm{c}}$ & $21.25 \pm 0.18^{\mathrm{b}}$ & $5.94 \pm 0.13^{\mathrm{d}}$ & $1.87 \pm 0.10^{\mathrm{ab}}$ & $64.02 \pm 1.60^{\mathrm{cd}}$ \\
$\mathrm{R}_{6}$ & $12574.43 \pm 16.79$ & $71.22 \pm 0.08^{\mathrm{d}}$ & $21.59 \pm 0.26^{\mathrm{c}}$ & $4.22 \pm 0.07^{\mathrm{b}}$ & $1.75 \pm 0.08^{\mathrm{a}}$ & $63.83 \pm 1.54^{\mathrm{cd}}$ \\
$\mathrm{R}_{7}$ & $12555.93 \pm 14.81$ & $68.58 \pm 0.12^{\mathrm{b}}$ & $21.63 \pm 0.23^{\mathrm{c}}$ & $5.79 \pm 0.26^{\mathrm{d}}$ & $2.32 \pm 0.06^{\mathrm{d}}$ & $78.40 \pm 2.36^{\mathrm{f}}$ \\
$\mathrm{R}_{8}$ & $12587.45 \pm 12.57$ & $69.22 \pm 0.06^{\mathrm{c}}$ & $22.11 \pm 0.24^{\mathrm{d}}$ & $5.31 \pm 0.06^{\mathrm{c}}$ & $1.98 \pm 0.14^{\mathrm{b}}$ & $58.36 \pm 2.80^{\mathrm{ab}}$ \\
\hline
\end{tabular}

Different superscripts in the same column indicate significantly different $(\mathrm{P}<0.05)$.

degradation by converting cholesterol to become bile acid, so that the cholesterol levels are reduced (Weiss and Scott, 1979). According to Rachmad and Wiradimadja (2011), the meat cholesterol levels will increase along with the increase blood of cholesterol levels, but it will reach its peak at a cholesterol level above $700 \mathrm{mg} / \mathrm{dL}$. A reduction of bile acid is one of the factors that are able to reduce cholesterol. Cholesterol is a bile acid forming compound. Body cholesterol is expelled through two primary channels: by changing cholesterol to become bile acid and through catabolism to become steroid hormones or neutral sterol formation like cholestanone and coprosterol. Changing cholesterol to bile acid is a cyclical change, because when cholesterol changes to bile acid it will be reabsorbed into liver and changed to cholesterol. As a result, the concentration of cholesterol in the body will not be reduced (Yulinery et al., 2006). Seeley et al. (2000) stated that secondary form of bile acid that is shaped to deoxycholic acid or lithocholic acid cannot be reabsorbed by the liver. Brook and Marshall (1996) revealed that bile salt which cannot be absorbed will be excreted through the feces, while Muray et al. (1999) claimed that bile acid which is conjugated in taurine or glycine are both mixed with pancreatic fluid and inside the ileum, bile acid binds with sodium or potassium and then reabsorbed, finally it is taken to the liver. As long as the amount of bile acid is still in a fixed amount, then the cholesterol that is found within the body will not be used. One of the ways to reduce cholesterol is by taking advantage of the body's homeostasis system.

\section{Meat Physical Quality}

The treatments using Pomacea canaliculata snails in feed have a significant effect $(\mathrm{P}<0.05)$ on water holding capacity, net cooking weight, and tenderness, but no significant effect $(\mathrm{P}>0.05)$ on meat $\mathrm{pH}$. The $\mathrm{pH}$ value was similar because ducks were raised in cages, so that their activities were relatively same, and after being slaughtered the lactate acid was similar. Therefore, the meat $\mathrm{pH}$ produced was not different (Table 3 ). In both treatments, the $\mathrm{pH}$ value was decrease as the proportion of Pomacea canaliculata snails in feed increase. This is suspected to be due to the use of Pomacea canaliculata snails in feed caused a reduction in meat fat levels. Soeparno (2011) reported that a reduction in water holding capacity can be caused by a reduction in meat protein and fat levels. The highest water holding capacity in this research was in the R0 treatment (without using Pomacea canaliculata snails in feed) at $49.23 \pm 0.19 \%$, while the lowest one was in R8 treatment (using 10\% Pomacea canaliculata 
Table 3. Physical Quality of Alabio Duck Meat (Moisture, Cooking Loss, Water Holding Capacity, pH, Tenderness) which was Fed with Snails in the Ration

\begin{tabular}{cccccc}
\hline Treatments & Moisture $(\%)$ & Cooking loss (\%) & $\begin{array}{c}\text { Water holding } \\
\text { capacity }(\%)\end{array}$ & pH & Tenderness \\
\hline $\mathrm{R}_{0}$ & $77.38 \pm 0.52^{\mathrm{c}}$ & $30.38 \pm 2.77^{\mathrm{c}}$ & $49.23 \pm 0.19^{\mathrm{d}}$ & $6.15 \pm 0.06$ & $2.88 \pm 0.13^{\mathrm{b}}$ \\
$\mathrm{R}_{1}$ & $73.89 \pm 0.58^{\mathrm{b}}$ & $28.80 \pm 1.14^{\mathrm{b}}$ & $41.92 \pm 3.06^{\mathrm{b}}$ & $6.20 \pm 0.02$ & $3.30 \pm 0.05^{\mathrm{d}}$ \\
$\mathrm{R}_{2}$ & $74.76 \pm 1.23^{\mathrm{b}}$ & $26.42 \pm 1.71^{\mathrm{a}}$ & $47.50 \pm 0.17^{\mathrm{d}}$ & $6.20 \pm 0.08$ & $3.42 \pm 0.17^{\mathrm{d}}$ \\
$\mathrm{R}_{3}$ & $73.89 \pm 2.31^{\mathrm{b}}$ & $30.28 \pm 1.65^{\mathrm{c}}$ & $38.79 \pm 0.65^{\mathrm{a}}$ & $6.20 \pm 0.08$ & $3.17 \pm 0.28^{\mathrm{c}}$ \\
$\mathrm{R}_{4}$ & $74.52 \pm 0.40^{\mathrm{b}}$ & $28.73 \pm 1.12^{\mathrm{b}}$ & $43.02 \pm 1.92^{\mathrm{c}}$ & $6.20 \pm 0.09$ & $3.23 \pm 0.20^{\mathrm{c}}$ \\
$\mathrm{R}_{5}$ & $73.91 \pm 0.60^{\mathrm{b}}$ & $30.02 \pm 1.23^{\mathrm{c}}$ & $42.22 \pm 0.16^{\mathrm{b}}$ & $6.20 \pm 0.08$ & $3.40 \pm 0.22^{\mathrm{d}}$ \\
$\mathrm{R}_{6}$ & $72.78 \pm 1.50^{\mathrm{ab}}$ & $32.99 \pm 1.21^{\mathrm{d}}$ & $40.06 \pm 2.33^{\mathrm{ab}}$ & $6.30 \pm 0.15$ & $3.02 \pm 0.17^{\mathrm{b}}$ \\
$\mathrm{R}_{7}$ & $71.42 \pm 1.72^{\mathrm{a}}$ & $31.46 \pm 0.66^{\mathrm{c}}$ & $38.85 \pm 4.17^{\mathrm{a}}$ & $6.30 \pm 0.08$ & $2.68 \pm 0.12^{\mathrm{a}}$ \\
$\mathrm{R}_{8}$ & $73.22 \pm 0.75^{\mathrm{ab}}$ & $30.71 \pm 1.36^{\mathrm{c}}$ & $37.72 \pm 2.84^{\mathrm{a}}$ & $6.30 \pm 0.12$ & $3.43 \pm 0.12^{\mathrm{d}}$ \\
\hline
\end{tabular}

Different superscripts in the same column rindicate significantly different $(\mathrm{P}<0.05)$.

snails from tidal swampy area) at $37.72 \pm 2.84 \%$.

A reduction in the $\mathrm{pH}$ value has been highly connected with the meat water holding capacity. This is supported by the opinion of Nurwantoro et al. (2011), who stated that a reduction in $\mathrm{pH}$ value is strongly connected with meat water holding capacity. The ability of meat to contain water or add water contain because there is an outside factors like slaughtering, cooking, or pressure. A reduction in water holding capacity is caused by changes in actin and myosin protein $\mathrm{pH}$, which approaches a meat isoelectric point after postrigor, so that it shortens the distance between protein filaments or reduces the ability of protein to hold water and will reduce the meat water holding capacity (Soeparno, 2011).

The use of Pomacea canaliculata snails in feed had a significant difference $(\mathrm{P}<0.05)$ towards meat tenderness (Table 3). The use of Pomacea canaliculata snails from tidal swampy area by $7.5 \%$ (R7) produce the most tenderness meat presumably because of unsaturated fatty acids that exist in snails that can increase marbling fat so the meat becomes juicy and flavour. There was also the possibility for $\mathrm{pH}$ value, water holding capacity and cooking loss of Alabio duck meat. Hoffman et al., (2003) reported that the $\mathrm{pH}$ value of the meat has a negative relationship with the power drop out of meat. Meat with high $\mathrm{pH}$ values tend to have low breaking power value thus at a higher $\mathrm{pH}$, the meat more tenderness.

\section{CONCLUSION}

Using Pomacea canaliculata snails in feed improve the physical quality and chemical quality of Alabio duck meat in intensively raised Alabio ducks. Using 5\% of Pomacea canaliculata snails in a mixture of Alabio duck basal feed produced a low cooking loss and low cholesterol content.

\section{ACKNOWLEDGEMENTS}

Gratitude was given to the Republic of Indonesia Ministry of Finance Educational Funding Management Institution (LPDP) for providing financial assistance for this research. Appreciation was conveyed to the Ministry of Agriculture of Agricultural Development and Research Agency for providing educational funds to continue to the $\mathrm{PhD}$ program. Gratefulness was also shown to the Gadjah Mada University especially Dean of Animal Science Faculty and all technicians who assisted in this research.

\section{REFERENCES}

Amrullah, I. K. 2004. Nutrisi Ayam Brolier. Cetakan ke-2. Lembaga Satu Gunung Budi. Bogor.

Anderson, J. W. 2003. Diet first, then medication for hypercholesterolemia. J. Amer. Med Association. 290:531-533. 
Astawan, M. 2009. Seimbangkan Omega 3 dan Omega 6. Penerbit Penebar Organization, Jakarta

Brook, G. D. C. and J. N. Marshall. 1996. Essential Endocrinology. $3^{\text {rd }}$ ed Oxford: Blackwell Science.

Direktorat Jenderal Peternakan dan Kesehatan Hewan. 2012. Statistik Peternakan dan Kesehatan Hewan. Kementerian Pertanian, Jakarta

Direktorat Jenderal Peternakan dan Kesehatan Hewan. 2013. Statistik Peternakan dan Kesehatan Hewan. Kementerian Pertanian, Jakarta

Hartoyo, B., I. Irawan and N. Iriyanti, 2005. The Influence of Varying Fatty Acids and Crude Fiber in Broiler Rations towards Cholesterol Levels, HDL and LDL Blood Serum. J. Anim. Prod. 7(1): 27-33

Hoffman, L.C., Muller, S.W.P. Cloete and D. Schmidt. 2003. Comparison of six crossbred lamb types: sensory, physical and nutritional meat quality characteristic. Meat Sci. 65: $1265-1274$

Ismoyowati and J. Sumarmono. 2011. Fat and cholesterol contents of local duck (Anas platyrhynchos) meat fed mash, paste and crumble feeds. Asian J. Poult. Sci. 5(4): 150-154.

Kinsella, J.E., K.S. Broughton and J.W. Whelan. 1990. Dietary unsaturated fatty acids interaction and possible need in relation to eicosanoid shyntesis. J. Nutr. Biochem. 1: 123-139.

Kortlang, C.F.H.F. 1985. The incubation of duck eggs. In : Farrel, D.J and Stapleton, P. (ed). Duck Production Science and World Practice. University of New England. P.167177

Krauss, R.M. 2001. Dietary and genetic effects on LDL heterogeneity. Nutrition and Fitness, Diet, Genes, Physical Activity and Health. In: Simopoulos, A.P., Pavlou, K.N., eds. World Review of Nutrition. S. Karger, Basel, Switzerland, Vol. 89, Chapter 12:1222. PMCID: 11530731

Muller, H., A.S. Lindman, A.L. Brantsaeter and J. I. Pedersen. 2003. The serum LDL/HDL cholesterol ratio is influenced more favorably by exchanging saturated with unsaturated fat than by reducing saturated fat in the diet of women. J. Nutr. 133:78-83.

Murray, R. K., D. K. Granner., P. A. Mayes and
V.W.R. Well. 1999. Biokimia. Translated by H. Andry. Penerbit buku kedokteran EGC. Jakarta. P. 260-262, 270-278, 581.

Noor, M. 2007. Rawa Lebak, Ekologi, Pemanfaatan, dan Pengembangannya. PT. Raja Grapindo Persada, Jakarta. 274 hal

Nurwantoro, V. P., A. Bintoro, M. Legowo, L. D. Ambara, A. Prakoso, S. Mulyani and A. Purnomoadi. 2011. Microbiological and physical properties of beef marinated with garlic juice. J. Indonesian Trop. Anim. Agric. 36:166-170

Rahmad, D. and R. Wiradimadja. 2011. Pendugaan kadar kolesterol daging dan telur berdasarkan kadar kolesterol darah pada puyuh Jepang. J. Ilmu Ternak. 11: 35-38.

Seeley, R.R., D.S. Trent and T. Philip. 2000. Anatomy and Physiology. 7th ed. New York: Mc Graw-Hill Co.

Setyawardani, T. D. Ningsih, D. Fernando and Acarwah. 2001. Pengaruh Pemberian Ekstrak Buah Nanas dan Pepaya terhadap Kualitas Daging Itik Petelur Afkir. Buletin Peternakan, Ed. Tambahan (Desember):146150.

Soeparno. 2011. Ilmu Nutrisi dan Gizi Daging. Cetakan ke-1, Gadjah Mada University Press, Yogyakarta.

Subhan, A., T. Yuwanta, H. P. S. Jafendi and E.S. Rohaeni. 2010. Pengaruh Pemberian kombinasi sagu kukus (Metroxylon Spp) dan tepung keong mas (Pomacea Spp) sebagai pengganti jagung kuning terhadap penampilan itik jantan Alabio, Mojosari dan MA. J. Ilmu Ternak dan Veteriner. 15(3): 165-173.

Weiss, F.G and M.L. Scott. 1979. The Effects of Dietary Fiber, Fat, and Total Energy upon Plasma Cholesterol and Other Parameters in Chickens. J.Nutr. 109: 693-701.

Winarno, F. G. 2008. Kimia Pangan dan Gizi. edisi terbaru.M-Brio Press, Bogor.

Woods, R, J. Mazziotta and S.R. Cherry. 1993. MRI-PET registration with automated algorithm. J Comput Assist Tomogr. 17(4):536-546.

Yulinery, T., E. Yulianto and N. Nurhidayat. 2006. Uji Fisiologis Probiotik Lactobacillus sp. Mar 8 yang Telah dienkapsulasi dengan Menggunakan Spray Dryer untuk Menurunkan Kolesterol. Biodiversitas. 7(2):118-122. 